\title{
Fertility status of soils under different land uses at Wujiraba watershed, North-western highlands of Ethiopia
}

\author{
Habtamu A. ${ }^{1,}$, , Heluf G. ${ }^{1}$, Bobe B. ${ }^{1}$, Enyew A. ${ }^{2}$ \\ ${ }^{1}$ Haramaya University, School of Natural Resources Management and Environmental Sciences, Ethiopia \\ ${ }^{2}$ Bahir Dar University, College of Agriculture and Environmental Science, Bahir Dar, Ethiopia
}

\section{Email address}

habtamuadmasu35@gmail.com (Habtamu A.)

\section{To cite this article:}

Habtamu A., Heluf G., Bobe B., Enyew A.. Fertility Status of Soils under Different Land uses at Wujiraba Watershed, North-Western Highlands of Ethiopia. Agriculture, Forestry and Fisheries. Vol. 3, No. 5, 2014, pp. 410-419. doi: 10.11648/j.aff.20140305.24

\begin{abstract}
In Ethiopian highlands, land use changes, mainly, from natural vegetation to cultivated lands brought about rapid nutrient depletion. Intensive and continuous cultivation of land without proper management resulted in decline in soil physical, chemical and biological properties which aggravate crop yield reduction and food shortage. The present study, therefore, is designed to investigate the effects of different land uses on soil fertility status in the Nitisols of Wujiraba watershed. Twenty seven soil samples were collected randomly depth wise $(0-15,15-30$ and $30-45 \mathrm{~cm})$ from the cultivated, forest and grazing lands. Data were analyzed using the two ways ANOVA in RCBD with three replications. Land use and soil depth showed a significant $(\mathrm{P} \leq 0.05)$ effect on soil physicochemical properties. The highest $f(57.8 \%), \mathrm{OC}(4.6 \%)$, total N $(0.28 \%)$, available $\mathrm{S}$ (11.1 ppm), CEC (42.2 cmol $\left.+\mathrm{kg}^{-1}\right)$, exchangeable bases $\left(\mathrm{Ca}(22.2), \mathrm{K}(0.76)\right.$ and $\left.\mathrm{Na}\left(0.58 \mathrm{cmol}^{-} \mathrm{kg}^{-1}\right)\right)$ and available micronutrients ( $\mathrm{Fe}$ (14.2), $\mathrm{Mn}(24.1)$ and $\mathrm{Zn}(2.9 \mathrm{ppm})$ ) were recorded on the surface layer of the forest land while lowest $\mathrm{pH} / \mathrm{KCl}(5.03)$ and highest available $\mathrm{P}(5.5 \mathrm{ppm})$ on the surface layer of cultivated land. The results revealed that soil fertility declines as land use changed from forest to grazing and cultivated lands. Hence, it is possible to infer that continuous and intensive cultivation depletes plant nutrients greatly which urge to take measures for maintaining its fertility status of the cultivated soils in the study area.
\end{abstract}

Keywords: Cultivated Land, Forest Land, Grazing Land, Land Use, Nutrient Depletion, Soil Fertility

\section{Introduction}

Soil productivity in Africa is declining as a result of soil erosion, nutrient and organic matter (OM) depletion [1]. In sub-Saharan Africa, soil fertility depletion is the fundamental cause for declining per capital food production as crop lands have a negative nutrient balance, with annual losses ranging from $1.5-7.1$ tons $\mathrm{ha}^{-1}\left(\mathrm{t} \mathrm{ha}^{-1}\right)$ of nitrogen $(\mathrm{N})$, phosphorus $(\mathrm{P})$ and potassium $(\mathrm{K})$ mainly due to crop harvest, leaching and low inputs applied to the soil [2, 3]. In the Ethiopian cultivated fields, about $42 \mathrm{t} \mathrm{ha}^{-1}$ of fertile soils have been lost every year [4] together with essential plant nutrients mainly due to poor soil management.

Assessing soil physicochemical properties are used to understand the potential status of nutrients in soils of different land uses $[5,6]$. To meet the food demands of rapid increasing population, vast tract of land are being cultivated more intensively and large areas of grass and forestlands are being overgrazed and deforested. Changes in land use and soil management can have a marked effect on soil fertility [7] mainly the conversion of natural ecosystem (forest land) to crop land which resulted in decline of soils physical, chemical and biological properties [8]. Research findings from different corners of the world have revealed that prolonged intensive cultivation and fertilization have resulted in the deterioration of plant nutrients $[9,10-11]$. Deforestation and cultivation of virgin tropical soils often lead to depletion of $\mathrm{N}, \mathrm{P}$, sulfur $(\mathrm{S})$ and other plant nutrients that lead to aluminum (Al), iron (Fe) and manganese (Mn) toxicity which increase soil acidity $[12,13,7,14]$.

Physical and chemical properties of the soils on land under continuous cultivation could vary from the other land uses $[15,16-17]$. Cultivated soils are poor in its fertility status as it has high bulk density $\left(\wp_{\mathrm{b}}\right)[18,19]$, low total porosity $(f)$ [20], low pH [21] and very low OM or organic carbon (OC) content [22, 23-24]. Cultivation has also altered other soil chemical properties and characterized by low in total $\mathrm{N}$ [25, $23,26,21]$, available S $[27,28]$, cation exchange capacity 
(CEC) [8] and exchangeable bases of calcium (Ca), magnesium $(\mathrm{Mg})$, potassium $(\mathrm{K})$ and sodium $(\mathrm{Na})[29,11,30]$ but relatively high in available $\mathrm{P}[31,16,7]$. The survival and well being of the present and future generation in countries with subsistence agriculture like Ethiopia depend on the extent of maintaining soil fertility [16]. So, land must be carefully managed which urges to establish land use system for conserving its fertility in the long term [17].

The factors causing nutrient depletion in the cultivated lands of highland Ethiopia include cultivation on steep and fragile soils, declining use of fallow, limited recycling of dung and crop residues to the soil, low application of external sources of plant nutrients, deforestation, overgrazing and torrential rainfall patterns [32, 33 - 35].Using crop residues as livestock feed and dung as fuel instead of fertilizer for instance is estimated to reduce Ethiopia's agricultural gross domestic product (GDP) by 7\% [36] where the study area is not escaped from these acute problems.

As soil physicochemical analyses results and its productivity level revealed that at present, Wujiraba watershed becomes nutrient depleted and less productive which make very difficult the efforts that have been made for improving crop yields. Besides, the degree, extent, causes and measures of the soil fertility decline have not received adequate research attention in the northwestern highlands of Ethiopia in general [37] and the study area in particular. Investigating soil physical and chemical properties under different land uses could assist policy makers, researchers, extension workers and farmers to have baseline information to improve the soil fertility and productivity of acid soils of the study area and elsewhere which have similar agroecology. Research on this line is of paramount importance as the results obtained from such studies could also be used for monitoring changes in soil fertility and productivity. Therefore, this study was conducted to assess soil fertility status of the soils under different land uses and soil depths at Wujiraba watershed in northwestern highlands of Ethiopia.

\section{Materials and Methods}

\subsection{Description of the Study Area}

The study was conducted at Wujiraba watershed, located in Chilga District of North Gondar Zone in the ANRS (Figure 1). The watershed is situated at about $60 \mathrm{~km}$ west of Gondar city and $760 \mathrm{~km}$ northwest of Addis Ababa (capital of Ethiopia). Geographically, the watershed lies at $12^{0} 32^{\prime}$ 16 " $-12^{\circ} 35$ ' $20^{\prime \prime} \mathrm{N}$ latitudes and $37^{\circ} 03$ ' $58^{\prime \prime}-37^{0} 06^{\prime} 23^{\prime \prime} \mathrm{E}$ longitudes with an area of $62.68 \mathrm{~km}^{2}$ and elevations ranging from 1910 and 2267 meters above sea level (m.a.s.1.). Three land uses were used for this study and such three land uses were cultivated, grazing and forest lands with soil groups of Nitisols [38].

Geologically, the study area is covered with thick trap series of volcanic rocks with structural complex which was notably active during the build-up of the mid-Tertiary flood basalt pile and middle-Tertiary volcanic mountains of the
Miocene and Pliocene-Quaternary, accompanied locally by predominantly basaltic volcanism. The trap volcanic series consists mainly of weathered and jointed basalt, and the soils of the study area were developed from the parent materials of volcanic origin, predominantly Tertiary basalt [39].

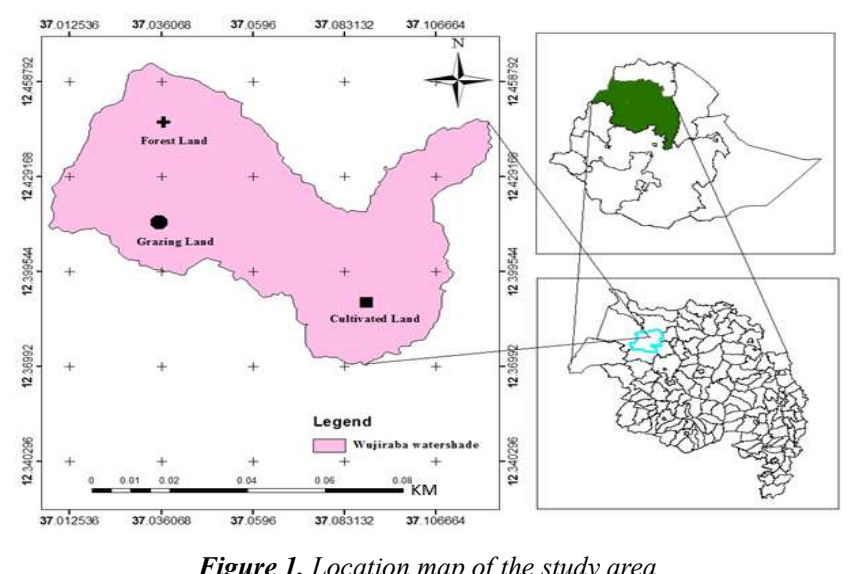

The watershed is characterized by unimodal rainfall pattern (Figure 2) that occurs from May to October. According to the weather data recorded at the Aykel Meteorological Station (3 $\mathrm{km}$ from the watershed), the ten years (2003-2012) total average annual rainfall for the study area was $1237 \mathrm{~mm}$. The annual mean minimum and maximum temperatures were 13.6 and $23.7{ }^{\circ} \mathrm{C}$, respectively.

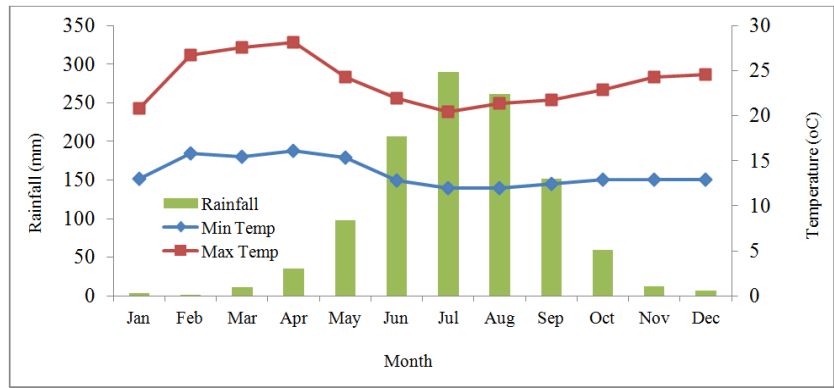

Figure 2. Mean monthly rainfall and maximum and minimum temperatures of the study area

The natural vegetation of Wujiraba watershed is very low except some trees and grasses on reserved areas. The trees occurring on slopes, mainly churches, are remnants of once dense evergreen forest. Currently, re-plantation strategy is being implemented dominated mainly by eucalyptus trees in the study area.

The economic activities of the local community of the study area are primarily mixed farming system that involves crop production and animal husbandry. In the Wujiraba watershed, the cultivated land accounts about $68.4 \%$ while the grazing, settlement and forest together with area closure lands account about 23.5, 5.3 and $2.8 \%$, respectively. The watershed is suitable for growing large variety of crops such as cereals, oil seeds, pulses, etc. The crops are grown in rotation by rain fed system. The land management systems for cultivation of such crops in the watershed include terracing, repeated contour plowing, application of chemical 
fertilizers, weeding and so on for better yield. However, there is no the practice of fallowing due to high population pressure.

\subsection{Land Use Selection and Soil Sampling}

Soil samples were collected in three land uses (forest, cultivated and grazing lands). Land use sites for soil sample takings were selected using the topographic map of the study area based on vegetation, grazing and cultivation history. At the beginning, a general visual field survey was carried out to have a general view of the variations in the study area. Regarding the history and management of the selected land uses, the cropland selected for this study has been under cultivation for more than a century whereas the grazing land was established on part of the former cropland 1981 onwards The forest land was formerly a forest and then being a natural reserve (church) since 1941. Global positioning system (GPS) and clinometers were used to read the geographical locations and slopes of the sampling sites of selected land uses, respectively.

From the cultivated lands, cereal crop land under rain fed condition was used while from the grazing lands and forest lands, communal grazing land and natural forest land (reserved area) were selected. Representative soil sampling sites were selected randomly from each land use according to their slope. Three representative fields or blocks were selected from each land use, and from each block, composite soil samples were collected from thirteen soil sub-samples (spots) within three depths of $0-15,15-30$ and $30-45 \mathrm{~cm}$ using an auger.

During collection of soil samples; dead plants, furrow, old manures, wet spots, areas near trees and the like were excluded. The composited soil samples collected from representative land uses with three replications were then airdried, ground and passed through a 0.5 for total $\mathrm{N}$ and $\mathrm{OC}$ and $2 \mathrm{~mm}$ sieve for the analysis of other selected soil physicochemical properties. Separate core soil samples from each sampling depth were taken with a core sampler.

\subsection{Soil Analysis}

The soil physicochemical analysis was carried out at Bahir Dar Soil Testing and Soil Fertility Improvement and Amhara Design and Supervision Works Agency Soil Laboratory Centers using the standard laboratory procedures. Soil texture was determined by the Bouyoucos hydrometer [40]. Bulk density was determined from undisturbed soil samples using core samplers [41] while particle density $\left(\wp_{s}\right)$ was estimated by the psychnometer method [42]. Total porosity $(f)$ was calculated from the values of $\hat{p}_{\mathrm{b}}$ and $\mathrm{p}_{\mathrm{s}}$ as:

$$
f=\left(1-\frac{\hat{p b}}{\mathrm{ps}}\right) 100
$$

Soil $\mathrm{pH}$ was measured in suspension of 1:2.5 soils to potassium chloride $(\mathrm{KCl})$ solution ratio [43]. Total $\mathrm{N}$ was determined by micro-Kjedahl method [44], available $\mathrm{P}$ was determined by extraction with Bray II method [45] using
$0.03 \mathrm{M} \mathrm{NH} \mathrm{NH}_{4} \mathrm{~F}$ and $0.10 \mathrm{M} \mathrm{HCl}$ solution, $\mathrm{CEC}$ and exchangeable $\mathrm{Ca}, \mathrm{Mg}, \mathrm{K}$ and $\mathrm{Na}$ were extracted with $1 \mathrm{M}$ $\mathrm{NH}_{4} \mathrm{OAc}$ at $\mathrm{pH}$ 7. Exchangeable $\mathrm{Ca}$ and $\mathrm{Mg}$ in the extracts were analyzed using atomic absorption spectrophotometer, while $\mathrm{Na}$ and $\mathrm{K}$ were analyzed by flame photometer [46, 47]. Percentage base saturation (PBS) was calculated as the percent of the sum of the exchangeable bases $(\mathrm{Ca}, \mathrm{Mg}, \mathrm{K}$ and $\mathrm{Na}$ ) to the CEC of the soil. Organic carbon was determined by the chromate acid oxidation method [48] and available $\mathrm{S}$ by Turbidimetric method [49]. Available micronutrients (Fe, $\mathrm{Cu}, \mathrm{Zn}$ and $\mathrm{Mn}$ ) were extracted by diethylene triamine pentaacetic acid (DTPA) as described by [50] and all these micronutrients were measured by atomic absorption spectrophotometer. Descriptions based on ratings of plant nutrients were also undertaken.

\subsection{Statistical Analysis}

Data was subjected to analysis of variance (ANOVA) with randomized completed block design (RCBD) method using SAS software [51]. A two-ways analysis of variance (ANOVA) was performed to assess the significance of differences in soil parameters between land uses, soil depths and their interaction effects. Treatment means were compared using least significant differences (LSD) by Fisher's test at 0.05 . Correlation and regression analyses were also conducted among soil parameters.

\section{Results and Discussion}

\subsection{Effects of Land Use on Selected Soil Physical Properties}

In this study, selected physical properties of soil such as texture, $\hat{\mathrm{b}}_{\mathrm{b}}, \hat{\mathrm{p}}_{\mathrm{s}}$ and $f$ were analyzed and presented in Table 1 . Sand, silt and clay fractions were highly significantly $(\mathrm{P} \leq$ $0.001)$ affected by land use and soil depth interactions. The highest sand and silt fractions (33.9 and 40.9\%) were observed on the surface layer $(0-15 \mathrm{~cm})$ of forest land while the highest clay content $(73.4 \%)$ was recorded in the subsurface layer $(30-45 \mathrm{~cm})$ of cultivated land which might be due to high leaching (lessivage) of clay particles down the profile in cultivated land. In all land uses, clay content increased while sand and silt contents decreased with increasing soil depths. These findings were in line with that of Eyayu et al. [52] who reported that the overall mean soil depth showed higher sand and lower clay content in the 0 $40 \mathrm{~cm}$ than in the $40-60 \mathrm{~cm}$ soil depths Tera Gedam watershed, north-western Ethiopia.

Bulk density was highly significantly $(\mathrm{P} \leq 0.001)$ affected by the interaction effect of land use and soil depth where the highest $\left(1.3 \mathrm{~g} \mathrm{~cm}^{-3}\right)$ was observed on the surface layer of grazing land and lowest $\left(0.9 \mathrm{~g} \mathrm{~cm}^{-3}\right)$ on the surface layer of forest land (Table 1) which might be due to the effects of high compaction by grazing animals in grazing and cultivated lands and high OM content in forest land. These results were in agreement with that of Puget and Lal [53]: [6] who stated that lower $\oint_{\mathrm{b}}$ was observed in forest land relative 
to cultivated and pasture lands. Similarly, Matersha and Mkhabela [18]: [19. 8] reported that virgin forest soil produced lower $\hat{\beta}_{\mathrm{b}}$ than crop and pasture lands because of the well-developed fine-medium granular structure and high $\mathrm{OM}$ contents.

Although $\hat{p}_{\mathrm{s}}$ was not significantly $(\mathrm{P}>0.05)$ affected by land use, soil depth and their interactions (Tables 1), the highest $\left(2.3 \mathrm{~g} \mathrm{~cm}^{-3}\right)$ was recorded on the surface layer of cultivated land which might be due to its high sand content and the presence of heavy minerals of Fe and Mn (Table 4) which was in agreement with the findings of [16]. However, $\hat{p}_{\mathrm{s}}$ of the study area is generally low which might be due to its high clay particle contents.

Total porosity was significantly $(\mathrm{P}<0.01)$ affected by land use and soil depth interactions (Table 1) where the highest $(57.8 \%)$ was observed on the surface layer of forest land and lowest $(43.0 \%)$ on the surface layer of grazing land which might be due to high $\mathrm{OM}$ in forest land and compaction with high $\hat{b}_{\mathrm{b}}$ in grazing land. The results were in agreement with that of Iris et al. [20] who reported that conservation tillage management resulted in a better pore connectivity than the conventional system. Heluf [54] also reported that OM influences soil physical properties by encouraging granulation, assisting aggregate (structure) stability, helping aggregation of soil particles, improving aeration and water holding capacities and reducing plasticity and cohesion. There was high significant $(\mathrm{P} \leq 0.001)$ and very strong negative correlation $(r=-0.97)$ between total porosity and $\hat{p}_{b}$ in the study area which indicated compaction acts as a strong impediment for soil porosity, aeration and root penetration of crops (Table 5).

Table 1. Interaction effects of land use and soil depth on particle sizes, bulk density, particle density and total porosity

\begin{tabular}{|c|c|c|c|c|c|c|}
\hline Treatments & Sand $(\%)$ & Silt (\%) & Clay $(\%)$ & Bulk Density $\left(\mathrm{g} \mathrm{cm}^{-3}\right)$ & Particle Density $\left(\mathrm{g} \mathrm{cm}^{-3}\right)$ & Total Porosity (\%) \\
\hline C,D1 & $16.2 \mathrm{~d}$ & $35.5 \mathrm{bc}$ & $48.3 b$ & $1.27 \mathrm{a}$ & $2.32 \mathrm{a}$ & $44.4 \mathrm{~cd}$ \\
\hline $\mathrm{C}, \mathrm{D} 2$ & $8.5 \mathrm{e}$ & $23.8 \mathrm{e}$ & $67.8 \mathrm{a}$ & $1.11 \mathrm{c}$ & $2.27 \mathrm{ab}$ & $51.2 \mathrm{~b}$ \\
\hline C,D3 & $10.2 \mathrm{e}$ & $16.4 \mathrm{f}$ & $73.4 \mathrm{a}$ & $1.09 \mathrm{c}$ & $2.22 b$ & $50.4 \mathrm{~b}$ \\
\hline F,D1 & $33.9 \mathrm{a}$ & $40.9 \mathrm{a}$ & $25.2 d$ & $0.95 \mathrm{~d}$ & $2.25 \mathrm{ab}$ & $57.8 \mathrm{a}$ \\
\hline $\mathrm{F}, \mathrm{D} 2$ & $20.2 \mathrm{~cd}$ & $38.4 \mathrm{ab}$ & $41.3 b c$ & $1.16 \mathrm{abc}$ & $2.28 \mathrm{ab}$ & $48.9 \mathrm{bc}$ \\
\hline F,D3 & $15.4 d$ & $37.2 \mathrm{ab}$ & $47.4 b$ & $1.25 \mathrm{ab}$ & $2.29 \mathrm{ab}$ & $46.2 \mathrm{bcd}$ \\
\hline G,D1 & $26.6 b$ & $35.7 \mathrm{bc}$ & $37.7 \mathrm{c}$ & $1.274 \mathrm{a}$ & $2.24 b$ & $43.0 \mathrm{~d}$ \\
\hline G,D3 & $22.3 b c$ & $30.0 \mathrm{de}$ & $47.7 b$ & $1.1 \mathrm{c}$ & $2.21 \mathrm{~b}$ & $50.1 \mathrm{~b}$ \\
\hline $\mathrm{R}^{2}$ & 0.92 & 0.92 & 0.95 & 0.79 & 0.55 & 0.75 \\
\hline CV $(\%)$ & 14.73 & 8.99 & 8.46 & 5.68 & 1.94 & 6.31 \\
\hline F-test & $* * *$ & $* * *$ & $* * *$ & $* * *$ & NS & $* * *$ \\
\hline $\operatorname{LSD}(0.05)$ & 5.03 & 4.99 & 7.06 & 0.11 & 0.08 & 5.34 \\
\hline
\end{tabular}

Means with the same letter are not significantly different at $\mathrm{P} \leq 0.05$ according to Fisher's $\mathrm{LSD} ; \mathrm{C}=$ cultivated land, $\mathrm{F}=$ forest land, $\mathrm{G}=$ grazing land, $\mathrm{D} 1=$ soil depth $0-15 \mathrm{~cm}, \mathrm{D} 2=$ soil depth $15-30 \mathrm{~cm}, \mathrm{D} 3=$ soil depth $30-45 \mathrm{~cm}$ soils.

\subsection{Effects of Land Use on Soil Chemical Properties}

Soil chemical properties are the most important factors that affect soil fertility and determine the nutrient supplying power of soil to the plants and microbes. In this study, the most important soil chemical properties were analyzed and presented in Tables 2 - 4 .

\subsubsection{Soil pH, Organic Carbon, Total Nitrogen, Available Sulfur and Phosphorus}

Soil $\mathrm{pH} / \mathrm{KCl}$ was significantly $(\mathrm{P} \leq 0.05)$ affected by the interaction effect of land use and soil depth where the highest (5.0) was observed in the subsurface layer of grazing land and lowest (4.45) on the surface layer of cultivated and grazing lands (Table 2). This could be due to continuous removal of basic cations by harvested crops and animal grazing on the surface layers of cultivated and grazing lands, respectively, and very high leaching of bases and clay particles from the exposed surfaces of cultivated lands as well as $\mathrm{H}^{+}$ion released by the nitrification of $\mathrm{NH}_{4}^{+}$sourced chemical fertilizers and legume roots during $\mathrm{N}_{2}$ fixation on the surface layer of cultivated land.

Similar research results were found by Malo et al. [55]: $[56,21]$ who stated that soil $\mathrm{pH}$ values were significantly lower on the surface layer for cultivated soils when compared to non-cultivated soils due to the application of $\mathrm{NH}_{4}{ }^{+}$sourced fertilizers to cultivated lands that nitrifies $\mathrm{NH}_{4}{ }^{+}$ and its uptake by the crops. Besides, the presence of higher $\mathrm{pH}$ in forest land might be accredited to the ameliorating effect of the high content of $\mathrm{OM}$ that form $\mathrm{Al}$ and $\mathrm{Fe}-\mathrm{OM}$ complexes and release of hydroxyl ions as well as deposition of basic cations [6]. However, opposite findings were reported by Yimer et al. [57] who stated that high $\mathrm{pH}$ values were recorded for croplands as compared to grazing and forest lands in the Bale mountain areas of Ethiopia. Lalisa et al. [35] also reported oppositely that soil $\mathrm{pH}$ decreased with increasing soil depth for land uses in Central highlands of Ethiopia. In this study, besides high significant $(\mathrm{P} \leq 0.001)$ and strong positive association $(\mathrm{r}=0.63)$ between $\mathrm{pH}$ and exchangeable $\mathrm{Mg}$, it was also significantly $(\mathrm{P} \leq 0.01)$ and positively correlated $(\mathrm{r}=0.5,0.55$ and 0.58$)$ with CEC, PBS and $\mathrm{Na}$, respectively (Table 5).

Organic carbon was highly significantly $(\mathrm{P} \leq 0.001)$ affected by the interaction effects of land use and soil depth (Table 2) whereby the highest $(4.6 \%)$ was observed on the surface layer of forest land and lowest $(1.0 \%)$ in the subsurface layer of cultivated land that showed an increase of $347.6 \%$ which might be due to high OM content and its oxidation on the surface layer of forest and cultivated lands, 
respectively. Wakene and Heluf [58]: [59, 52] reported that lower levels of soil OM content was observed in cultivated land. Moscatelli et al. [22]: [23] also indicated that clearing tropical forests and conversion into farmland lowered by 20 $50 \%$ in soil OM content as cultivation generally aerates the soil and increases OM oxidation rates. Similarly, Guo and Gifford [60]: [24 indicated that soils lost $42-59 \%$ of their soil OC stock upon conversion from forest to crop land in northeastern China and others. Organic carbon was highly significantly $(\mathrm{P} \leq 0.001)$ and strongly positively correlated $(\mathrm{r}$ $=0.86,0.77,0.73$ and 0.7 ) with total $\mathrm{N}, \mathrm{Zn}, \mathrm{Fe}$ and $\mathrm{Ca}$, respectively in this study (Table 5) which might be due to all of them sourced from OM. As per the classification rate suggested by Tekalign [61], the OC for forest land qualified as high while grazing and cultivated lands medium and low status, respectively for the study area.

Total $\mathrm{N}$ was significantly $(\mathrm{P} \leq 0.05)$ affected by land use and soil depth interactions (Table 2) where the highest $(0.28 \%)$ was recorded on the surface layer of forest land and lowest $(0.12 \%)$ on the surface layer of cultivated land which might be due to high OM content in forest land and its rapid oxidation and/or mineralization in cultivated land. These results were in agreement with that of Tiejun et al. [23]: [21] who reported that changes in soil OM could lead to changes in total $\mathrm{N}$ and long term cultivation without organic fertilizers usually leads to a decrease in soil OC and total $\mathrm{N}$ contents because organic forms generally account for more than $95 \%$ of soil N. Similarly, Lemma et al. [25]: [62, 26] elucidated that the contribution of $\mathrm{OM}$ to total $\mathrm{N}$ is high and soil $\mathrm{N}$ content decreased by 64 and $55 \%$ in cultivated sites compared to native forest and rangeland, respectively by which afforestation also increased total N. However, Puget and Lal [53] (2005) reported oppositely that pasture soil contained the highest $\mathrm{N}$ stocks than forest and cultivated lands in the top $5 \mathrm{~cm}$ layer. Malo et al. [55] also reported that total $\mathrm{N}$ was high on the surface layer of forest land but reduced with increasing soil depth by $50 \%$ for each subsequent depth increment in both the cultivated and noncultivated soils. In this study, total $\mathrm{N}$ was negatively correlated $(\mathrm{r}=-0.21)$ with soil $\mathrm{pH}$ which might be due to the slow rate of $\mathrm{OM}$ oxidation and/or $\mathrm{N}$ mineralization as microorganisms especially nitrifying bacteria (Rhizobium) are sensitive to acidic environments as shown in Table 5. According to the ratings suggested by Landon [63], forest land qualified for medium while grazing and cultivated lands low in its total $\mathrm{N}$ status in this study.

High significant $(\mathrm{P} \leq 0.001)$ difference was observed in available $\mathrm{S}$ by the interaction effects of land use and soil depth where the highest (11.1 ppm) was observed on the surface layer of forest land and lowest $(2.8 \mathrm{ppm})$ in the subsurface layer of cultivated land that showed an increase of $293.9 \%$ which might be due to high OM content on the surface layer of forest land (Table 2). These results were supported by Zhihui et al. [64] who stated that farm yard manure (FYM) application increased the OC and S content of the soil in which up to $98 \%$ of the total soil S may be present as organic S compounds. Wakene [16] also reported that the highest total $\mathrm{S}$ was observed on the surface layer of virgin land and decreased with soil depth due to low OM contents. Similarly, Balsa et al. [27]: [28] reported that intensive cropping has resulted in higher $S$ removal and depletion in the soil. Based on the report of Blair et al. [65], the critical level of available $\mathrm{S}$ is $6.5 \mathrm{ppm}$ for optimum crop production although [66] reported $10 \mathrm{ppm}$ as the critical value for available $\mathrm{S}$ in soils. The cultivated soil of the study area, therefore, is below the critical level. In this study, available $\mathrm{S}$ was also highly significantly $(\mathrm{P} \leq 0.001)$ and strongly positively correlated $(\mathrm{r}=0.680 .73$ and 0.78$)$ with $\mathrm{OC}, \mathrm{CEC}$ and $\mathrm{Zn}$, respectively (Table 5) as all of these nutrients are mainly the result of OM decomposition. Probert [67] reported similar results that the profile of organic S content generally follows the pattern of $\mathrm{OM}$ in soils with soil depth.

Table 2. Interaction effects of land use and soil depth on pH, organic carbon, total nitrogen, available phosphorus and sulfur

\begin{tabular}{|c|c|c|c|c|c|}
\hline Treatments & $\mathrm{pH} / \mathrm{KCl}$ & Available sulphur (ppm) & Organic carbon (\%) & Total nitrogen (\%) & Available phosphorus (ppm) \\
\hline C,D1 & $4.45 b$ & $2.9 \mathrm{~d}$ & $1.84 \mathrm{de}$ & $0.16 \mathrm{~d}$ & $5.5 \mathrm{a}$ \\
\hline $\mathrm{C}, \mathrm{D} 2$ & $4.86 \mathrm{a}$ & $2.9 \mathrm{~d}$ & $1.27 \mathrm{f}$ & $0.15 d$ & $4.1 \mathrm{~b}$ \\
\hline C,D3 & $4.98 \mathrm{a}$ & $2.8 \mathrm{~d}$ & $1.03 \mathrm{f}$ & $0.12 \mathrm{~d}$ & $2.2 \mathrm{c}$ \\
\hline F,D1 & $5.00 \mathrm{a}$ & $11.1 \mathrm{a}$ & $4.61 \mathrm{a}$ & $0.21 \mathrm{a}$ & $3.8 \mathrm{~b}$ \\
\hline F,D2 & $4.93 \mathrm{a}$ & $10.1 \mathrm{ab}$ & $2.45 \mathrm{c}$ & $0.19 b$ & $3.7 b$ \\
\hline F,D3 & $4.95 \mathrm{a}$ & $9.1 \mathrm{~b}$ & $2.00 \mathrm{e}$ & $0.18 \mathrm{bc}$ & $3.0 \mathrm{bc}$ \\
\hline G,D1 & $4.45 b$ & $4.4 \mathrm{c}$ & $2.90 \mathrm{~b}$ & $0.27 \mathrm{a}$ & $2.9 \mathrm{bc}$ \\
\hline G,D3 & $5.00 \mathrm{a}$ & $4.1 \mathrm{dc}$ & $1.93 \mathrm{de}$ & $0.14 \mathrm{~d}$ & $3.5 b$ \\
\hline $\mathrm{R}^{2}$ & 0.86 & 0.97 & 0.98 & 0.96 & 0.76 \\
\hline $\mathrm{CV}(\%)$ & 2.47 & 13.13 & 8.45 & 6.35 & 18.54 \\
\hline F-test & $*$ & $* * *$ & $* * *$ & $*$ & $* *$ \\
\hline LSD (0.05) & 0.21 & 1.3 & 0.33 & 0.019 & 1.13 \\
\hline
\end{tabular}

Means with the same letter are not significantly different at $\mathrm{P} \leq 0.05$ according to Fisher's $\mathrm{LSD} ; \mathrm{C}=$ cultivated land, $\mathrm{F}=$ forest land, $\mathrm{G}=$ grazing land, $\mathrm{D} 1=$ soil depth $0-15 \mathrm{~cm}, \mathrm{D} 2=$ soil depth $15-30 \mathrm{~cm}, \mathrm{D} 3=$ soil depth $30-45 \mathrm{~cm}$ soils.

Available $\mathrm{P}$ content of the soil was significantly $(\mathrm{P} \leq 0.01)$ affected by the combined effects of land use and soil depth (Tables 2) whereby the highest $(5.5 \mathrm{ppm})$ was recorded on the surface layer of cultivated land which might be due to the application of DAP fertilizer. These results were in agreement with that of Tekalign et al. [31]: [16, 7] Wakene 
who indicated that available $\mathrm{P}$ in cultivated land was higher than grazing and forest lands. Similarly, Iris et al. [20] reported that mineral $\mathrm{P}$ fertilization resulted in the building up of plant available $\mathrm{P}$ in the top soil compared to nonfertilized plots and decreased with increasing soil depth [68, 55]. There was high significant $(\mathrm{P} \leq 0.01)$ and positive correlation $(\mathrm{r}=0.58)$ between available $\mathrm{P}$ and total $\mathrm{N}$ as shown in Table 5.

\subsubsection{Cation Exchange Capacity, Exchangeable Bases (Ca, $\mathrm{Mg}, \mathrm{K}$ and $\mathrm{Na}$ ) and Percentage Base Saturation}

Cation exchange capacity was highly significantly $(\mathrm{P} \leq$ 0.001 ) affected by the interaction effects of land use and soil depth (Tables 3) where the highest $\left(42.2 \mathrm{cmol}(+) \mathrm{kg}^{-1}\right)$ was recorded on the surface layer of forest land while lowest $\left(31.6 \mathrm{cmol}(+) \mathrm{kg}^{-1}\right)$ on the surface layer of cultivated land which might be due to high OM content on the surface layer of forest land but low OM, high leaching of basic cations and clay from cultivated land. Henry [69]: [18, 8] reported that when humus is combined with clay, it increased soil CEC, and plant residues with OC content of $40-50 \%$ have increased soil's negative charge while low $\mathrm{pH}$ reduces CEC. Gao and Chang [70]: [71] stated that CEC is highly and positively correlated with $\mathrm{OM}$, clay and $\mathrm{pH}$ but affected negatively by intensive cultivation. There was significant $(\mathrm{P}$ $\leq 0.01)$ and positive correlation $(\mathrm{r}=0.58)$ between CEC and $\mathrm{OC}$ in this study. Analogous to OC, there was high significant $(\mathrm{P} \leq 0.001)$ and strong positive associations $(\mathrm{r}=$ $0.76,0.73,0.65$ and 0.66 ) between CEC, and exchangeable $\mathrm{Ca}$, available $\mathrm{S}$, exchangeable $\mathrm{Mg}$ and available $\mathrm{Zn}$, respectively (Table 5).

Table 3. Interaction effects of land use and soil depth on cation exchange capacity, exchangeable bases and percentage base saturation

\begin{tabular}{|c|c|c|c|c|c|c|}
\hline \multirow[b]{2}{*}{ Treatments } & \multirow{2}{*}{ Cation exchange capacity $\left(\mathrm{cmol}(+) \mathrm{kg}^{-1}\right.$} & \multicolumn{4}{|c|}{ Exchangeable bases (cmol(+) $\mathrm{kg}^{-1}$} & \multirow{2}{*}{ Percentage base saturation (\%) } \\
\hline & & Calcium & Magnesium & Potassium & Sodium & \\
\hline C,D1 & $31.6 \mathrm{e}$ & $8.6 \mathrm{f}$ & $1.4 \mathrm{~d}$ & $0.71 \mathrm{ab}$ & $0.19 \mathrm{c}$ & $34.4 \mathrm{f}$ \\
\hline $\mathrm{C}, \mathrm{D} 2$ & $33.5 \mathrm{de}$ & $11.1 \mathrm{ef}$ & $4.5 \mathrm{c}$ & $0.48 \mathrm{c}$ & $0.21 \mathrm{c}$ & $48.7 \mathrm{e}$ \\
\hline C,D3 & $35.1 \mathrm{~cd}$ & $12.1 \mathrm{def}$ & $5.6 \mathrm{bc}$ & $0.45 \mathrm{~cd}$ & $0.28 \mathrm{c}$ & $52.30 \mathrm{c}$ \\
\hline F,D1 & $42.2 \mathrm{a}$ & $22.2 \mathrm{a}$ & $6.3 a b c$ & $0.77 \mathrm{a}$ & $0.55 \mathrm{a}$ & $70.5 \mathrm{ab}$ \\
\hline F,D2 & $37.4 b c$ & $19.3 \mathrm{ab}$ & $7.1 \mathrm{ab}$ & $0.58 b c$ & $0.49 \mathrm{ab}$ & $73.5 \mathrm{a}$ \\
\hline F,D3 & $39.9 \mathrm{ab}$ & $15.2 \mathrm{~cd}$ & $8.1 \mathrm{a}$ & $0.59 b c$ & $0.33 b c$ & $60.6 \mathrm{~cd}$ \\
\hline G,D1 & $34.8 \mathrm{cde}$ & $14.1 \mathrm{cde}$ & $2.2 \mathrm{~d}$ & $0.68 \mathrm{ab}$ & $0.31 \mathrm{c}$ & $49.8 \mathrm{e}$ \\
\hline G,D2 & $36.0 \mathrm{~cd}$ & $17.2 \mathrm{bc}$ & $4.9 \mathrm{c}$ & $0.47 \mathrm{c}$ & $0.50 \mathrm{a}$ & $63.9 b c$ \\
\hline G,D3 & $37.2 b c$ & $17.1 \mathrm{bc}$ & $5.9 b c$ & 0.31 & $0.51 \mathrm{a}$ & $63.9 b c$ \\
\hline R2 & 0.81 & 0.87 & 0.85 & 0.79 & 0.78 & 0.89 \\
\hline CV (\%) & 5.39 & 13.28 & 22.36 & 16.67 & 24.78 & 9.01 \\
\hline F-test & $* * *$ & $* * *$ & $* * *$ & $* *$ & ** & $* * *$ \\
\hline $\operatorname{LSD}(0.05)$ & 3.4 & 3.4 & $1 . .98$ & 0.16 & 0.16 & 8.9 \\
\hline
\end{tabular}

Means with the same letter are not significantly different at $\mathrm{P} \leq 0.05$ according to Fisher's LSD; $\mathrm{C}=$ cultivated land, $\mathrm{F}=$ forest land, $\mathrm{G}=$ grazing land, $\mathrm{D} 1=$ soil depth $0-15 \mathrm{~cm}, \mathrm{D} 2=$ soil depth $15-30 \mathrm{~cm}, \mathrm{D} 3=$ soil depth $30-45 \mathrm{~cm}$ soils

Exchangeable $\mathrm{Ca}$ was highly significantly $(\mathrm{P} \leq 0.001)$ affected by the interaction effects of land use and soil depth (Table 3). The highest exchangeable Ca $\left(22.2 \mathrm{cmol}(+) \mathrm{kg}^{-1}\right)$ was observed on the surface layer of forest land where as lowest $\left(8.6 \mathrm{cmol}(+) \mathrm{kg}^{-1}\right)$ on the surface layer of cultivated land with an increase of $158 \%$ which might be due to high $\mathrm{OM}$ and relatively high $\mathrm{pH}$ on the surface layer of forest land and its leaching from the surface layer of cultivated land. Baker et al. [29]: [30] reported that cultivation led to reduction and leaching of exchangeable cations, especially in acidic tropical soils. In this study, exchangeable Ca showed high significant $(\mathrm{P} \leq 0.001)$ and strong positive correlation $(\mathrm{r}$ $=0.7$ and 0.9 ) with $\mathrm{OC}$ and PBS, respectively (Table 5) which might be due to its source from OM and it is one of the most abundant basic cations surrounding the colloidal soil surface. According to the ratings recommended by FAO [72], the soil is ranged medium in cultivated land to very high in forest land in its exchangeable Ca content.

Exchangeable $\mathrm{Mg}$ was also highly significantly $(\mathrm{P} \leq 0.001)$ affected by the interaction effect of land use and soil depth where the highest $\left(8.1 \mathrm{cmol}(+) \mathrm{kg}^{-1}\right)$ was observed in the subsurface layer of forest land and lowest $\left(1.4 \mathrm{cmol}(+) \mathrm{kg}^{-1}\right)$ on the surface layer of cultivated land (Table 3 ) that indicated a decrease of $82.7 \%$ which might be due to low OM content, low $\mathrm{pH}$ and high leaching of exchangeable $\mathrm{Mg}$ from the cultivated land. He et al. [11] reported that the lowest exchangeable $\mathrm{Mg}$ was obtained in cultivated land which could be due to the high intensity of cultivation and abundant crop harvest with little or no use of inputs. The value of exchangeable $\mathrm{Mg}$ in the study area was highly significantly $(\mathrm{P} \leq 0.001)$ and strongly positively correlated $(\mathrm{r}=0.65$ and 0.73 ) with CEC and PBS, respectively. According to FAO's [72] rating, soils of the study area are ranged medium in cultivated land to very high in forest land in its exchangeable $\mathrm{Mg}$ content.

Exchangeable $\mathrm{K}$ was significantly $(\mathrm{P} \leq 0.01)$ affected by land use and soil depth interactions (Tables 3 ) whereby the highest $\left(0.76 \mathrm{cmol}(+) \mathrm{kg}^{-1}\right)$ was recorded on the surface layer of forest land while lowest $\left(0.31 \mathrm{cmol}(+) \mathrm{kg}^{-1}\right)$ in the subsurface layer of grazing land which might be due to high $\mathrm{OM}$ on the surface layer of forest land and high compaction or $\hat{p}_{\mathrm{b}}$ in grazing land. This result was in agreement with that of Baker et al. [29]: [16] who found that lower exchangeable $\mathrm{K}$ contents in cultivated and grazing lands than in the forest land. Barber [73] reported that the critical level of exchangeable $\mathrm{K}$ in the soil for most crops for $\mathrm{K}$ fertilizer requirement is $0.38 \mathrm{cmol}(+) \mathrm{kg}^{-1}$ and therefore, the content of exchangeable $\mathrm{K}$ is above the threshold level in the soils of 
the study area for crop growth with no $\mathrm{K}$ fertilizer requirement in the plow layer of cultivated lands. Similarly, Smaling et al. [74] reported that crop responses to $\mathrm{K}$ fertilization are rare in Africa due to high exchangeable $\mathrm{K}$ contents in many parts of Africa.

Exchangeable $\mathrm{Na}$ was significantly $(\mathrm{P} \leq 0.05)$ affected by land use and soil depth interactions (Tables 3). The highest exchangeable $\mathrm{Na}\left(0.58 \mathrm{cmol}(+) \mathrm{kg}^{-1}\right)$ was recorded on the surface layer of forest land and lowest $\left(0.19 \mathrm{cmol}(+) \mathrm{kg}^{-1}\right)$ on the surface layer of cultivated land that increased by $205.3 \%$ which might be due to their high OM content and leaching, respectively. According to FAO's [72] rating, the soil was qualified as low in cultivated land and medium in forest and grazing lands, respectively for their exchangeable $\mathrm{Na}$ contents.

Exchangeable $\mathrm{Ca}$ and $\mathrm{Mg}$ were by far higher than $\mathrm{K}$ and $\mathrm{Na}$ in all land uses of the study area since divalent cations were higher in macro-aggregate fractions than the

monovalent once which was similar to the report of [30]. Mamo [17] also reported that deforestation, leaching, limited recycling of dung and crop residues, declining fallow periods and soil erosion have contributed to depletion of basic cations and reduction in CEC in cultivated land as compared to the adjacent forest land.

Percentage base saturation was also highly significantly ( $\mathrm{P}$ $\leq 0.001)$ affected by land use and soil depth interactions (Table 3). In this study, the highest PBS (73.5\%) was observed in the subsurface layer of forest land where as lowest $(34.4 \%)$ on the surface layer of cultivated land which might be due to relatively high OM and clay contents (soil colloidal sites and storehouse of exchangeable bases) in the subsurface layer of forest land compared to the surface layers of cultivated and grazing lands.

\subsubsection{Micronutrients (Available Iron, Manganese, Copper and zinc)}

\begin{tabular}{cccc} 
Available iron (ppm) & Available manganese (ppm) & Available copper (ppm) & Available zinc (ppm) \\
\hline $7.2 \mathrm{c}$ & $21.2 \mathrm{a}$ & $2.38 \mathrm{ab}$ & $0.89 \mathrm{de}$ \\
$6.4 \mathrm{~cd}$ & $13.7 \mathrm{bc}$ & $1.81 \mathrm{bc}$ & $0.49 \mathrm{~cd}$ \\
$4.5 \mathrm{~d}$ & $12.6 \mathrm{c}$ & $1.61 \mathrm{c}$ & $0.41 \mathrm{~d}$ \\
$14.2 \mathrm{a}$ & $24.1 \mathrm{a}$ & $2.71 \mathrm{a}$ & $2.85 \mathrm{a}$ \\
$11.8 \mathrm{ab}$ & $16.9 \mathrm{~b}$ & $2.58 \mathrm{a}$ & $1.34 \mathrm{~b}$ \\
$12.8 \mathrm{ab}$ & $14.8 \mathrm{bc}$ & $2.46 \mathrm{a}$ & $1.07 \mathrm{bc}$ \\
$12.6 \mathrm{ab}$ & $14.1 \mathrm{bc}$ & $2.23 \mathrm{ab}$ & $0.38 \mathrm{e}$ \\
$11.1 \mathrm{~b}$ & $3.5 \mathrm{~d}$ & $1.60 \mathrm{c}$ & $0.55 \mathrm{de}$ \\
$11.2 \mathrm{~b}$ & $2.8 \mathrm{~d}$ & $1.55 \mathrm{c}$ & $0.39 \mathrm{e}$ \\
0.90 & 0.95 & 0.74 & 0.94 \\
13.69 & 14.42 & 16.17 & 27.16 \\
$* * *$ & $* * *$ & $* *$ & $* * *$ \\
2.42 & 3.43 & 0.59 & 0.43 \\
\hline
\end{tabular}

Means with the same letter are not significantly different at $\mathrm{P} \leq 0.05$ according to Fisher's LSD; Note: $\mathrm{C}=$ cultivated land, $\mathrm{F}=$ forest land, $\mathrm{G}=$ grazing land, D1 = soil depth $0-15 \mathrm{~cm}, \mathrm{D} 2=$ soil depth $15-30 \mathrm{~cm}, \mathrm{D} 3=$ soil depth $30-45 \mathrm{~cm}$ soil

Table 5. Pearson's correlation matrix for various soil physicochemical parameters

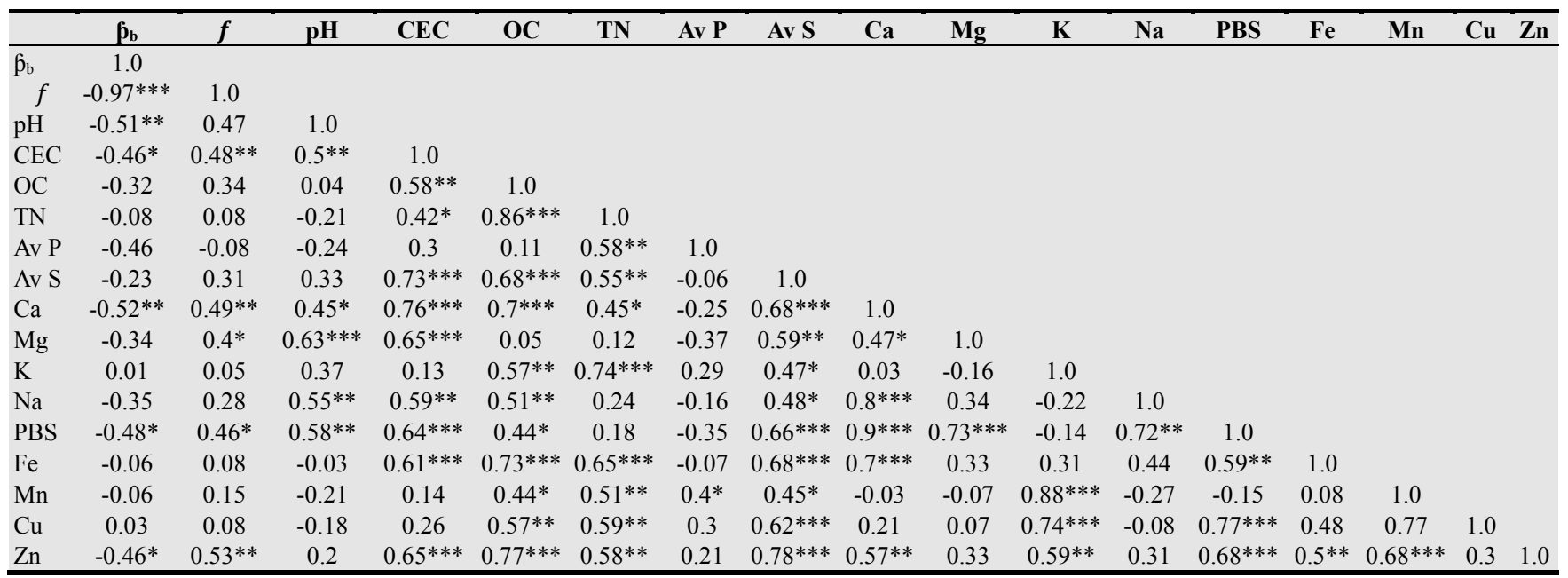

***Significant at $\mathrm{P}=0.001 ; * *$ significant at $\mathrm{P}=0.01 ; *$ significant at $\mathrm{P}=0.05$ levels; $\mathrm{TN}=$ total nitrogen; Av. $\mathrm{P}=$ available $\mathrm{P} ;$ Av. $\mathrm{S}=$ available $\mathrm{S}$

High significant $(\mathrm{P} \leq 0.001)$ differences were observed in available micronutrients of $\mathrm{Fe}, \mathrm{Mn}$ and $\mathrm{Zn}$ contents by the interaction effect of land uses and soil depths where the highest $(14.2,24.1$ and $2.9 \mathrm{ppm})$ were observed on the surface layer of forest land (Table 4) which might be due to high OM concentrations that acted as a chelating effect and source of such micronutrients. Significant $(\mathrm{P} \leq 0.01)$ difference was also observed in $\mathrm{Cu}$ content by which the 
highest (2.7 ppm) was recorded on the surface layer of forest land that might be also due to its high OM contents. Mamo [17] reported that OM may promote the availability of such nutrients by supplying soluble complexing agents or organic acids that interfere with their fixation. These results were also supported by Wakene [16]: [7] who stated that micronutrients content increased with the increase in OM and total N. In this study, available $\mathrm{Fe}, \mathrm{Mn}, \mathrm{Cu}$ and $\mathrm{Zn}$ had significant $(\mathrm{P} \leq 0.05)$ and strong positive correlation $(\mathrm{r}=0.73$, $0.44,0.57$ and 0.77 ) with OC in their orders (Table 5).

Lindsay and Norvell [75] indicated that the critical levels of available $\mathrm{Fe}$ and $\mathrm{Mn}$ for crop production are $>40$ and 48 ppm, respectively. Therefore, according to the suggestions made by them, the soil of the study area was below the toxicity level of $\mathrm{Fe}$ and $\mathrm{Mn}$ nutrients for producing crops.

\section{Conclusions}

Land use has significant impacts on soil physicochemical properties in the study area. Forest land, due to its strong protection, was found to be low in $\hat{p}_{\mathrm{b}}$, high in total porosity $f$, and better in OC, total $\mathrm{N}$ and available $\mathrm{S}, \mathrm{CEC}$, exchangeable bases and micronutrients content especially on the surface layer. Although it is clayey in texture and relatively better in available $\mathrm{P}$, cultivated land was poorer in soil nutrients with lower $\mathrm{pH}$ which has become limiting for crop production. This signals the great need for soil nutrient amelioration measures such as integrated nutrient management (application of organic and inorganic fertilizers), growing of $\mathrm{N}_{2}$ fixing crops and application of agro-forestry into the farming systems so that soil total porosity, $\mathrm{pH}, \mathrm{OC}$, total $\mathrm{N}$, available $\mathrm{S}$ and $\mathrm{P}, \mathrm{CEC}$, exchangeable bases and micronutrient contents will be improved and enabled production of sufficient food for the farm households by minimizing nutrient depletion and keeping such acidic soil fertile.

\section{Acknowledgements}

We thank to the Ministry of Education for its financial grant through the Haramaya University. We also acknowledge the staff members, especially laboratory technicians at the Bahir Dar Soil Testing and Fertility Improvement Center for their logistic and technical supports during analysis of soil samples. We also acknowledge ANRS agriculture Bureau for its logistic support.

\section{References}

[1] K.. Abreha. "Soil Acidity Characterization and Effects of Liming and Chemical Fertilization on Dry Matter Yield and Nutrient Uptake of Wheat (Triticum Aestivum L.) on Soils of Tsegede District, Northern Ethiopia”. PhD Dissertation, Haramaya University, Ethiopia. 2013.

[2] J.K. Adesodun,, E.F. Adeyemi and C.O. Oyegoke. "Distribution of nutrient elements within water-stable aggregates of two tropical agro ecological soils under different land uses”. Soil and Tillage Research. 92: 190-197. 2007.

[3] H. Ahmed. "Assessment of Spatial Variability of Some Physicochemical Properties of Soils under Different Elevations and Land Use Systems in the Western Slopes of Mount Chilalo, Arsi". MSc Thesis, Alemaya University, Ethiopia. 111p. 2002.

[4] F.R Akamigbo and C.A. Asadu. "The influence of parent materials on the soils of Southeastern Nigeria". East African Agriculture and Forest Journal, 48: 81-91. 2001.

[5] M. Alexandra, R. Charles, B. Jeangros and S. Sinaj. "Effect of organic fertilizers and reduced-tillage on soil properties, crop nitrogen response and crop yield: Results of a 12-year experiment in Changins, Switzerland". Soil and Tillage Research. 126:11-18. 2013.

[6] V.B. Allen and D.J. Pilbeam. "Handbook of Plant Nutrition, Taylor and Francis Group”. 2007.

[7] A.P. Aluko, and J.A. Fagbenro. "The role of tree species and land use systems in organic matter and nutrient availability in degraded Ultisol of Onne, Southeastern Nigeria". Proc. Annual Conf. Soil Science Society of Nigeria. 3: 89-292. . 2000.

[8] J. Arshad, Y.S. Moon and M.Z. Abdin, "Sulfur -a general overview and interaction with nitrogen". Australian Journal of Crop Science. 4: 523-529. 2010.

[9] M.R. Baker, C. Nys and J.F. Picard. "The effects of liming and gypsum application on a sessile oak (Quercus petraea) stand at Larcroix- Scaille (French Ardennes)". Site characteristics, soil chemistry and aerial biomass. Plant and Soil. 150: 99-108. 1997.

[10] M.E. Balsa, Serrao, M.G., Martins, M.M., Castelo-Branco, M.A., Gusmao, M.R. and M.L. Fernandes. "Effects of Pyrite Residue Amendment on Sulfur Availability in a Calcareous Soil Cropped with Sown Pasture in Fertilizers and Environment" C. Rodriguez-Barrueco, editor. Kluwer academic Publ., Printed in the Netherlands. pp 453-455. 1996.

[11] K. Banafshe,, N. Nili, F. Nourbakhsh, B. Sharifnabi and H. Khademi. "Does cultivation influence the content and pattern of soil proteins"? Soil and Tillage Research. 111: 162-167. 2011.

[12] T.C. Barauah, and H.P. Barthakulh. "A Text Book of Soil Analysis". Vikas Publishing House, New Delhi, India. 1997.

[13] S. Barber, 1984. "Soil Nutrient Bioavailability". Mechanistic Approach. J. Wiley and Sons, Inc. New York, 398p.

[14] P. Barry, and J. Ejigu. "Soil Fertility Practices in Wolaita Zoe, Southern Ethiopia: Learning from Farmers, Policy and Research Series”. 2005.

[15] A. Bationo, B. Waswa, J. Kihara and J. Kimetu. "Advances in Integrated Soil Fertility Management in Sub-Saharan Africa: Challenges and Opportunities". Springer, Dordrecht, the Netherlands. 2007.

[16] S. Belay. "Integrated watershed management approach to sustainable land management (Experience of SARDP in East Gojjam and South Wollo)". pp.127-136. In: Tilahun Amede (Ed.). In: Proceedings of the Conference on the Natural Resource Degradation and Environmental Concerns in the Amhara National Regional State: Impact of Food Security, July 24-26, 2002, Bahir Dar. The Ethiopian Society of Soil Science. Addis Ababa, Ethiopia. 2003. 
[17] G.J. Blair, N. Chinoim, R.D.B. Lefroy, G.C. Anderson and G.J Croccker. "A soil sulfur test for pastures and crops". Australian Journal of Soil Resources. 29: 619-626. 1991.

[18] H.R. Bray and L.T. Kurtz. "Determination of organic and available forms of phosphorus in soils". Soil Science. 9: 39-46. 1945.

[19] R. Cardelli, F. Marchini, and A. Saviozzi. "Soil organic matter characteristics, biochemical activity and antioxidant capacity in Mediterranean land use systems". Soil and Tillage Research. 120: 8-14. 2012.

[20] H.D. Chapman. "Cation exchange capacity". In: C. A. Black, L. E. Ensminger and F. E. Clark (Eds). Methods of soil analysis. Agronomy. 9: 891-901. American Society of Agronomy. Inc., Madison, Wisconsin.

[21] S.H. Chopra, and J.S. Kanwar. "Analytical agricultural chemistry”, Kalyani Publisher. 1976.

[22] J. Chorowicz, B. Collet, F.F. Bonavia, P. Mohr, J.F. Parriot and T. Kome. "The Tana basin, Ethiopia: Intra-plateau uplift, rifting and subsidence". Elseivier. 295:351-367. 1998.

[23] R. Diaz, M., J. Buenob, S.J. Gonza'lez-Prietoa and T. Carballasa. "Cultivation effects on biochemical properties, C storage and $15 \mathrm{~N}$ natural abundance in the $0-5 \mathrm{~cm}$ layer of an acidic soil from temperate humid zone". Soil and Tillage Research. 84: 216-221. 2005.

[24] P.R. Day. "Particle fraction and particle size analysis". In: Black CA et al. (Eds). Methods of Soil Analysis. Part 2. American Society of Agronomy. pp. 545 -567. 1965.

[25] M. Eyayu, H. Gebrekidan, T. Mamo and M. Assen. "Effects of land use change on selected soil properties in the Tera Gedam Catchment and adjacent agro-ecosystems, north-west Ethiopia". Ethiopian Journal of Natural Resources. 11: 35-62. 2009.

[26] FAO (Food and Agriculture Organization). "Plant Nutrition for Food Security: A Guide for Integrated Nutrient Management". FAO, Fertilizer and Plant Nutrition Bulletin No. 16, Rome. 2006a.

[27] FAO (Food and Agriculture Organization). "World reference base for soil resources: A framework for international classification, correlation and communication". $2^{\text {nd }}$ Edition, World Soil Resources Reports No. 103. FAO, Rome. 2006b.

[28] G. Gao, and C. Chang. "Changes in cation exchange capacity and particle size distribution of soils associated with longterm annual applications of cattle feed lot manure". Soil Science. 161: 115-120. 1996.

[29] T. Gebeyaw. "Soil Fertility Status as Influenced by Different Land Uses in Maybar Areas of South Wello zone, North Ethiopia". M.Sc. thesis, Haramaya University, Ethiopia. 2007.

[30] G. Gebreyohannes. Spatial Variability of Selected Soil Properties and Degree of Degradation of Soils in Betmera watershed, Northern highland of Ethiopia. M.Sc. Thesis Alemaya University, Ethiopia. 148p. 2001.

[31] L.B. Guo and R.M. Gifford. "Soil carbon stocks and land use change: a meta analysis". Global Change and Biology. 8: 345360. 2002.

[32] Z.L. He, A.K. Alva, D.V. Calvert, Y.C. Li and D.J. Banks. "Effects of nitrogen fertilization of grapefruit trees on soil acidification and nutrient availability in Riviera fine sand". Plant and Soil. 206: 11-19. 1999.
[33] G. Heluf. "Chemistry, Colloidal Properties and Dynamics of Soil Organic Matter Advanced Soil Chemistry". Haramaya University. 2009

[34] J. Henao and C. Baanante. "Agricultural Production and Soil Nutrient Mining in Africa: Implication for Resource Conservation and Policy Development". IFDC Tech. Bull. International Fertilizer Development Center. Muscle Shoals, Al. USA. 2006

[35] D.F. Henry. "Fundamentals of Soil Science". Eighth Edition, Michigan State University, John Wiley and Sons, New York. 1990.

[36] H. Hurni. "Land Degradation, Famine and Land Resource Scenarios in Ethiopia". In: D. Pimentel (ed), World Soil Erosion and Conservation. Cambridge University press. 1993.

[37] IFPRI (International Food Policy Research Institute). "Fertilizer and Soil Fertility Potential in Ethiopia, Constraints and Opportunities for Enhancing the System". Working Paper. pp. 2-3. 2010

[38] V. Iris, J. Rogasik, U. Funder, K. Panten and E. Schnug. "Effect of tillage systems and P-fertilization on soil physical and chemical properties, crop yield and nutrient uptake". Soil and Tillage Research. 103:137-143. 2009.

[39] M.L. Jackson. "Soil Chemical Analysis". Prenstice-Hall, Inc., Engle Wood Cliffs. New Jersey. pp. 183-204. 1958.

[40] C.M. Joao, C.C. Cerri, R. Lal, W.A. Dick, M.C. Piccolo, and B. E. Feig. "Soil organic carbon and fertility interactions affected by a tillage chronosequence in a Brazilian Oxisol". Soil and Tillage Research. 104: 56-64. 2009.

[41] C.G. Kowalenko. "A modified apparatus for quick and versatile sulfate sulfur analysis using hydriodic acid reduction". Communication in Soil Science and Plant Analysis. 1985.

[42] A.D. Lalisa, H. Hager and M. Sieghardt. "Effects of Land Use Types on Soil Chemical Properties in Smallholder Farmers of Central Highland Ethiopia”. Pp. 1-14. 2010.

[43] J.R. Landon. "Booker Tropical Soil Manual: A Handbook for Soil Survey and Agricultural Land Evaluation in the Tropics and Subtropics". Longman Scientific and Technical, Essex, New York. 474p. 1991.

[44] B. Lemma, D. Berggren, I. Nilsson and M. Olsson. "Soil carbon sequestration under different exotic tree species in the southwestern highlands of Ethiopia". Geoderma. 136: 886-898. 2006.

[45] W.L. Lindsay and W.A. Norvell. "Development of a DTPA soil test for $\mathrm{Zn}, \mathrm{Fe}, \mathrm{Mn}$ and Cu". Soil Science Society of American Journal. 42: 421-428. 1978.

[46] D.D. Malo, T.E. Schumacher and J.J. Doolittle. "Long-term cultivation impacts on selected soil properties in the northern Great Plains". Soil and Tillage Research. 81:277-291. 2005.

[47] Y. Mamo. "Influence of Land Use Systems on Selected Soil Physical and Chemical Properties at Agedit Watershed, South Gondar Zone, Amhara Regional State". M.Sc. thesis, Haramaya University, Ethiopia. 2011.

[48] S.A. Matersha, and T.S. Mkhabela. "Influence of land use on properties of ferralitic soil under low external input farming in Swaziland". Soil and Tillage Research. 62: 15-25. 2001.

[49] M.C. Moscatelli, A. Di Tizio, S. Marinari, and S. Grego. "Microbial indicators related to soil carbon in Mediterranean land use systems". Soil and Tillage Research. 97: 51-59. 2007. 
[50] M.E. Probert. "Sulfur in Australia". In: Freney JR, Nicholson AJ (eds), Australian Academy of Science, Canberra. pp. 158-169.

[51] P. Puget and R. Lal. "Soil organic carbon and nitrogen in a Mollisol in central Ohio as affected by tillage and land use". Soil and Tillage Research. 80:201-213. 2005.

[52] W.D. Reynolds, C.F. Drury, C.A. Fox and T.Q. Zhang. "Land management effects on the near-surface physical quality of a clay loam soil”. Soil and Tillage Research. 96: 316-330. 2007.

[53] D.L. Rowell. "Soil Science: Methods and Applications". Addison Wesley Longman Limited. England. 350p. 1994.

[54] D.L. Rowell. "Soil Science: Method and Application". Addison Wesley Longman Group UK, Singapore. 1997.

[55] S. Sahlemedhin and T. Bekele. "Procedure for Soil and Plant Analysis". National Soil Research Centre, Ethiopian Agricultural Research Organization, Addis Ababa, Ethiopia. 2000.

[56] H. Saikhe, C. Varadachari and K. Ghosh. "Changes in carbon, nitrogen and phosphorus levels due to deforestation and cultivation. A Case study in Simplipal National Park", India. Plant and Soil. 198:137-145. 1998a.

[57] H. Saikhe, C. Varadachari and K. Ghosh. "Effects of deforestation and cultivation on soil CEC and contents of exchangeable bases. A case study in Simplipal National Park", India. Plant and Soil. 204:67-75. 1998b.

[58] P.A. Sanchez and B.A. Jama. "Soil fertility replenishment takes off in East and Southern 9Africa. In: Integrated Plant Nutrient Management in sub-Saharan Africa: From concept to practice". B. Vanlauwe, J. Diels, N. Sanginga and R. Merckx (Eds.). CAB Int., Wallingford, UK. pp. 23-45. 2002.

[59] SAS (Statistical Analysis System). "SAS User's Guide": Statistics Released 6.12. SAS. Inst. Inc. cary NC, USA. 2002.

[60] H. Singh, K.N. Sharma and B.S. Arora." Influence of continuous fertilization to a maize system on the changes in soil fertility". Fertility Research. 40: 7-19. 1995.

[61] E.A. Smaling, S.M. Nandwa, and B.H. Janssen. "Soil Fertility in Africa is at Stake". p. 47-61. In R.J. Buresh et al. (ed.) Replenishing Soil Fertility in Africa. SSSA Spec. Publ. 51. SSSA, Madison, WI (this publication). 1997.

[62] B. Taye and A. Yifru. "Assessment of Soil Fertility Status with Depth in Wheat Growing Highlands of Southeast Ethiopia". World Journal of Agricultural Science. 6: 525-531. 2010.

[63] A.E. Tegenu, H.T. Kassahun, A.S. Collick, T. Adissu, B.B. Ashagrie, Z.K. Tessema, A. Derebe, D. Solomon and T.S. Steenhus. "Soil Properties and Fertility Status Dynamics of Northwestern Ethiopia Influenced by Land Use Changes: Case of Dibanke Watershed". M.Sc. Thesis, Haramaya University, Ethiopia. 2008.
[64] M Tekalign, I. Haque, and C.S. Kamara. "Phosphorus Status of Ethiopian Vertisols: Management of Vertisols in SubSaharan Africa”. pp. 232-252. Proceeding of the Conference Held at International Livestock Centre for Africa (ILCA), 31 August-4 September 1987. 1988.

[65] T. Tekalign. "Soil, Plant, Water, Fertilizer, Animal Manure and Compost Analysis". Working Document No. 13. International Livestock Research Center for Africa, Addis Ababa. 1991.

[66] Z. Tiejun, Y. Wanga, X. Wang, Q. Wangc and J. Han. "Organic carbon and nitrogen stocks in reed meadow soils converted to alfalfa fields". Soil and Tillage Research. 105:143-148. 2007.

[67] A.M. Urioste, G. G. Hevia, E.N. Hepper, L.E. Anton, A.A. Bono and D.E. Buschiazzo. "Cultivation effects on the distribution of organic carbon, total nitrogen and phosphorus in soils of the semiarid region of Argentinian Pampas". Geoderma. 136:621-630. 2006.

[68] N.C. Wakene. “Assessment of Important Physicochemical Properties of Nitosols under Different Management Systems in Bako area, Western Ethiopia". (M.Sc. thesis), Alemay University, Ethiopia. 2001.

[69] N. Wakene and G. Heluf. "Influence of land management on morphological, physical and chemical properties of some soils of Bako, Western Ethiopia”. Agropedology. 13:1-9. 2003.

[70] A. Walkley and C.A. Black. "An examination of different methods for determining soil organic matter and the proposed modification by the chromic acid titration method". Soil Science. 37: 29-38. 1934.

[71] T. Wondwosen and S. Beyene. "Identification of growth limiting nutrient(s) in Alfisols: Soil physico-chemical properties, nutrient concentrations and biomass yield of maize". American Journal of Plant Nutrition and Fertilization Technology. 1: 23-35. 2011.

[72] D. Xueli, X. Han, Y. Liang, Y. Qiao, L. Li, and N. Li. "Changes in soil organic carbon pools after 10 years of continuous manuring combined with chemical fertilizer in a Mollisol in China". Soil and Tillage Research. 122: 36-41. 2012.

[73] F. Yimer, S. Ledin and A. Abdulakdir. "Changes in soil organic carbon and total nitrogen contents in three adjacent land use types in the Bale Mountains, southeastern highlands of Ethiopia". Forest Ecology Management. 242: 337-342. 2007.

[74] G. Zenebe. "Household Fuel and Resource Use in RuralUrban Ethiopia". Wageningen University, the Netherlands. 2007.

[75] Y. Zhihui, B.R. Singh, and S. Hansen. "Aggregate associated carbon, nitrogen and sulfur and their ratios in long-term fertilized soils". Soil and Tillage Research. 95: 161-171. 2007. 